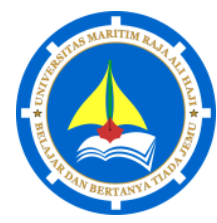

Jurnal Anugerah, 2(1) (2020)

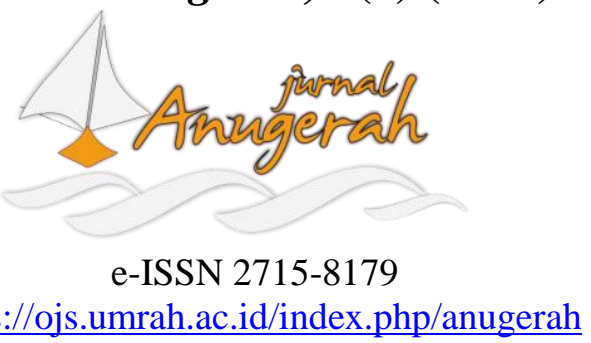

\title{
Pemahaman Objek Abstrak Matematika Guru Sekolah Menengah Atas di Kabupaten Bintan
}

\author{
Febrian $^{1 *}$, Puji Astuti ${ }^{2}$ \\ 1,2 Universitas Maritim Raja Ali Haji, Senggarang, Tanjungpinang, Kepulauan Riau 29115, Indonesia \\ *e-mail korespondensi: febrian@umrah.ac.id
}

Pengiriman: 1 Mei 2020; Diterima: 24 Mei 2020; Publikasi: 31 Mei 2020

DOI: https://doi.org/10.31629/anugerah.v2i1.2270

\begin{abstract}
Abstrak
Matematika memiliki objek kajian abstrak yang terbagi menjadi menjadi empat yakni fakta, konsep, prosedur, dan prinsip. Pemahaman pada empat objek krusial ini menentukan pemahaman lebih baik terhadap matematika yang berimbas pada kualitas mengajar matematika oleh guru. Mengingat pentingnya memahamai objek matematika tersebut, maka dilakukan penelusuran melalui Focus Group Discussion terhadap 17 guru matematika SMA Kabupaten Bintan, Kepulauan Riau. Melalui teknik ini digali informasi mengenai pemahaman guru meliputi bagaimana guru mendefinisikan dan memberikan contoh pada masing-masing objek tersebut. Data kualitatif dianalisis secara deskriptif meliputi reduksi data, penyajian data, dan kesimpulan. Agar dapat menginterpretasi situasi, maka digunakan teori yang memungkinkan terbangunnya kesimpulan empiris. Hasil menunjukkan hanya objek fakta yang dapat didefinisikan dengan baik dengan pemberian contoh yang tepat dan luwes. Objek prosedur dipahami oleh semua guru, tetapi pemberian contoh terbatas hanya pada konteks bilangan. Konsep sebagai sebuah objek didefinisikan sebagai ide abstrak dan diasosiakan sebagai definisi oleh tidak lebih dari sepertiga guru dengan pemberian contoh terbatas. Pandangan mengenai konsep sebagai semua konten termuat dalam materi merupakan hal yang juga muncul di kalangan guru. Prinsip sebagai objek yang paling rumit tidak dipahami oleh semua guru dan di atas situasi tersebut pemberian contoh tidak dapat dilakukan.
\end{abstract}

Kata kunci: objek abstrak matematika; pemahaman; focus group discussion

\begin{abstract}
Mathematics has abstract objects divided into four: facts, concepts, procedures, and principles. Understanding these crucial objects will determine a better understanding of mathematics which then impacts the quality of teaching mathematics. A research was conducted through a Focus Group Discussion engaging 17 high school mathematics teachers in Bintan, Kepulauan Riau. Through this technique, information about the teacher's understanding of mathematical objects which includes how they define and give examples to all objects was explored. Qualitative data were analyzed descriptively including data reduction, data presentation, and conclusions. A theory is used to build empirical conclusions. The results show that only facts can be well defined by giving examples that are precise and flexible. The procedure object is understood by all teachers but limited only to giving examples about numbers. The concept object is defined as an abstract idea and is also associated as a definition by a third of the teachers with limited examples given. The view of the concept as all content contained in the material is also emerging among the teachers. The principle as the most complicated objects is not understood by all teachers and an example cannot be given.
\end{abstract}

Keywords: abstract mathematical object; understanding; focus group discussion 


\section{Pendahuluan}

Matematika merupakan subjek yang diajarkan pada semua level pendidikan. Konten matematika disusun sedemikian rupa dalam kurikulum satuan pendidikan dasar hingga perguruan tinggi. Adapun rasional termuatnya Matematika dalam kurikulum pendidikan serta diajarkan secara formal adalah adanya kepentingan untuk menata nalar pebelajar atau peserta didik serta untuk membentuk kepribadiannya (Mahmudi, 2009). Hal ini kiranya sepadan dengan tujuan pendidikan nasional. Pernyataan ini sangat dapat diterima mengingat matematika sebagai sebuah subjek yang dipelajari secara formal di bangku pendidikan memiliki karakteristik tertentu.

Banyak pendapat yang menjelaskan sejumlah karakteristik matematika. Diantaranya menyatakan bahwa matematika memiliki objek kajian yang abstrak, simbol yang kosong dari arti, memuat kesepakatan, serta pola pikir deduktif aksiomatik (Maarif, 2015). Namun dari sejumlah karakteristik tersebut, yang paling mendapat penekanan adalah karakternya yang abstrak. Hal ini pula yang membedakan matematika dengan bidang ilmu lain yang kita ketahui sampai saat ini (Ruseffendi, 2001).

Dikenal adanya dua jenis objek abstrak dalam matematika, yaitu objek langsung dan objek tak langsung. Objek langsung berkaitan dengan konten matematika yang dipelajari sedangkan objek tak langsung menyasar kepada sikap atau kemampuan siswa dalam pemecahan masalah, berpikir logis, kreatif, dan kritis (Sutiarso, 2009). Objek langsung (selanjutnya dituliskan objek asbtrak) yang mana menjadi fokus dalam penelitian ini dapat diurai menjadi sejumlah pengelompokkan berdasarkan sifat dan strukturnya. Hingga saat ini struktur konten matematika dapat dibagi menjadi 4 sesuai pendapat Gagne, diantaranya: (1) fakta, (2) konsep, (3) keterampilan, dan (4) prinsip (Bell, 1978). Selanjutnya Bell (1981) dalam (Mahmudi, 2009) mendefinisikan fakta sebagai sebuah kesepakatan; keterampilan sebagai prosedur atau operasi; konsep sebagai ide abstrak yang memungkinkan adanya penggolongan; dan prinsip sebagai objek komplet yang dapat berupa keterkaitan antar konsep.

Penguasaan terhadap empat abstrak matematika ini merupakan salah satu faktor penentu dalam keberhasilan memahami matematika dan strukturnya (Febrian et al., 2019). Oleh karena itu, dalam proses pembelajaran diperlukan upaya untuk mengakomodasi penguasaan objek abstrak matematika tersebut agar tujuan pembelajaran matematika dapat tercapai. Pembelajaran matematika sekiranya mampu menggiring peserta didik mencapai kemampuan kognitif hingga level yang tinggi dan mampu membuat mereka melakukan proses mental dalam pikirannya dengan cara mengaitkan satu objek dengan objek lainnya, serupa kaitan konsep dengan konsep lainnya. Atas dasar itulah, memahami matematika dengan benar dan cepat masih menjadi tantangan yang sulit (Sutiarso, 2009).

Namun, penguasaan akan objek abstrak matematika kiranya bukan sekadar tantangan bagi peserta didik namun juga bagi guru. Karena sifatnya yang abstrak tersebut, tidak jarang guru mengalami beberapa kendala dalam proses pembelajaran (Holisin, 2016). Atas dasar itulah, guru sejatinya harus dapat menguasai struktur konten matematika dan mengurainya menjadi empat objek yang harus diberikan treatment dalam proses pembelajaran secara unik untuk mengakomodasi penguasaan di kalangan peserta didik.

Agar dapat melihat fakta lapangan penguasaan objek asbtrak matematika di kalangan guru, maka sebuah penelusuran kemudian dilakukan. Meski sekalipun objek langsung matematika yang abstrak bukan hal yang baru bagi hampir semua pihak terlibat dalam pendidikan matematika, namun tidak ditemukan adanya penelusuran yang memfokuskan pada pemahaman guru tentang objek abstrak matematika secara utuh atau keseluruhan. Sejumlah penelitian yang telah ada dominan memfokuskan pada pemahaman salah satu objek, yaitu konsep matematika. Dengan demikian, penelitian ini akhirnya membangun sendiri signifkansinya dari awal.

Beranjak dari pemikiran tersebut, sebuah studi yang mampu menelaah pemahaman guru terhadap objek matematika abstrak dilakukan. Artikel ini memuat dua hal yang menjadi pertanyaan, yakni: 1) Bagaimana pemahaman guru terhadap objek abstrak matematika; 2) Bagaimana contoh dalam sejumlah 
topik matematika sekolah yang diberikan guru dalam mendukung definisi objek abstrak matematika yang telah diberikan sebelumnya.

\section{Metode}

Agar dapat menemukan jawaban atas pertanyaan yang ada dalam penelitian ini, maka dilakukan Focus Group Discussion (FGD) yang melibatkan peneliti dan sejumlah guru matematika yang tergabung dalam Musyawarah Guru Mata Pelajaran (MGMP) tingkat Sekolah Menengah Atas (SMA) Kabupaten Bintan. Terdapat 17 guru matematika yang berasal dari 10 SMA/SMK sederajat yang terdapat di Kabupaten Bintan, Kepulauan Riau. FGD didefinisikan sebagai teknik pengumpulan data secara sistematis yang didefinisikan secara sederhana menjadi sebuah diskusi yang diselenggarakan secara sistematis pula dan terarah mengenai suatu isu atau masalah tertentu (Irwanto, 2006; Siregar, 2018). Isu yang diangkat dalam FGD ini adalah pemahaman guru mengenai objek abstrak (langsung) dalam matematika. Diskusi diarahkan pada dua pertanyaan yang telah dirumuskan sebelumnya. Sebagai sebuah teknik pengumpulan data, FGD mengandalkan perolehan informasi dari informan melalui serangkaian interaksi dalam suatu kelompok yang berfokus dalam melakukan pembahasan tertentu (Lailly \& Wisudawati, 2015; Afiyanti, 2008). Teknik yang digunakan dalam FGD ini yaitu 1) sharing pengetahuan peserta mengenai karakteristik matematika; 2) tanya jawab yang diarahkan pada dua pertanyaan penelitian dengan teknik wawancara tidak terstruktur kepada setiap guru peserta; dan 3) pemberian arahan di akhir sesi.

FGD sendiri merupakan kegiatan pembuka dalam rangkaian roadmap kegiatan yang dilakukan dalam wujud Pengabdian kepada Masyarakat $(\mathrm{PkM})$ yang berjudul "Pelatihan Pengembangan Media Videoscribe dengan Konteks Lokal dalam Mengejarkan Objek Matematika bagi MGMP SMA Kabupaten Bintan" oleh Febrian et al., (2019) dan "Diseminasi Online Multimedia Pembelajaran Matematika yang Dikembangkan Menggunakan Videoscribe" oleh Astuti \& Febrian (2019). Pada kegiatan tersebut, FGD memiliki tujuan spesifik untuk menggali pemahaman guru terhadap objek langsung abstrak matematika.

Data dari FGD ini berbentuk kualitatif baik berupa narasi dan transkrip ketika tanya jawab dan diskusi terkait objek abstrak matematika dan pemberian contoh dan data numerik yang disajikan dalam tabel memuat informasi dalam bentuk persentase. Data kemudian dianalisis secara deskriptif melalui serangkain proses reduksi terhadap sejumlah respons guru, penyajian hasil dari FGD berkaitan dengan dua pertanyaan penelitian, dan kesimpulan yang difokuskan untuk menjawab dua pertanyaan penelitian: bagaimana pemahaman guru dan bagaimana contoh yang diberikan terkait objek matematika yang dapat memberikan informasi mengenai pemahaman aktual mereka. Demi mendukung kesimpulan yang empiris mengenai bagaimana guru mendefinisikan objek serta memberikan contoh masing-masingnya, penilaian secara teoretis terhadap respons-respons guru tersebut dilakukan. Respons guru yang mungkin muncul dikategorikan menjadi beberapa sebagai berikut: 1) tepat atau tidak tepat dengan berdasarkan teori; dan 2) tidak menjawab atau tidak memberikan respons.

\section{Hasil dan Pembahasan}

FGD dilakukan selama lebih kurang 1 jam yang melibatkan peneliti, pembantu peneliti, dan 17 guru SMA yang tergabung dalam MGMP Matematika SMA Kabupaten Bintan, Kepulauan Riau. Berikut dokumentasi kegiatan selama FGD berlangsung.

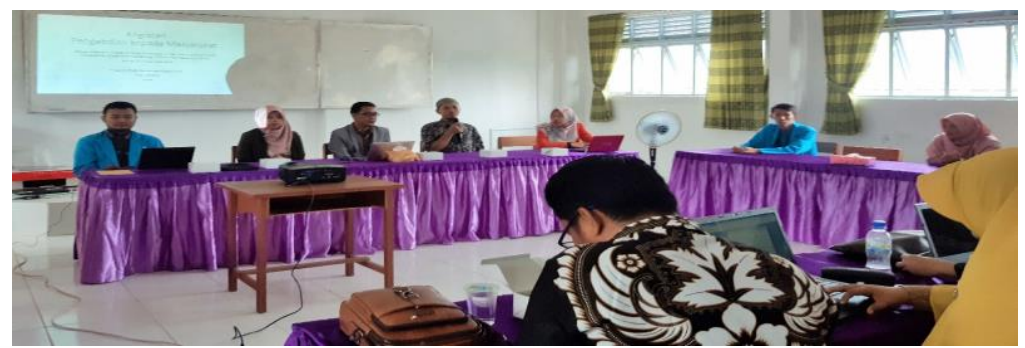

Gambar 1. Sesi sharing dan tanya jawab dalam FGD terkait pemahaman objek matematika 
Melalui FGD diperoleh beberapa informasi mengenai bagaimana guru mendefinisikan empat objek matematika melalui sesi sharing dan tanya jawab. Pertanyaan terkait bagaimana peserta mendefinisikan serta memberikan contoh objek abstrak matematika langsung ditujukan kepada masing-masing peserta sehingga respon dapat dianalisis secara langsung. Rekapitulasi hasil analisis terhadap data disajikan melalui Tabel 1 yang memuat data persentase penilaian terhadap respons sebagai berikut.

Tabel 1

Rekapitulasi Respon 17 Guru Peserta Terkait Objek Matematika Selama GFD

\begin{tabular}{ccccccc}
\hline & \multicolumn{3}{c}{ Pendefinisian objek matematika (\%) } & \multicolumn{3}{c}{ Pemberian contoh objek matematika (\%) } \\
\cline { 2 - 6 } & Tepat & Tidak tepat & Tidak Menjawab & Tepat & Tidak tepat & Tidak Menjawab \\
\hline Fakta & 100 & 0 & 0 & 100 & 0 & 0 \\
Konsep & 29,41 & 47,05 & 23,54 & 57,14 & 19,32 & 23,54 \\
Operasi & 100 & 0 & 0 & 100 & 0 & 0 \\
Prinsip & 0 & 0 & 100 & 0 & 0 & 100 \\
\hline
\end{tabular}

Berkaitan dengan objek fakta diperoleh infromasi bahwa semua guru dapat mendefinisikan objek ini sebagai sesuatu yang disepakati. Beberapa frasa seperti "sesuatu yang telah dianggap benar" dan "tidak perlu dipertanyakan lagi karena sudah disepakati" mewakili respons semua guru. Berdasarkan sejumlah respons terkait cara mendefinisikan objek pertama ini, dapat ditarik kata kunci yang membuat semuanya memiliki kesamaan, yaitu adanya kesepakatan. Pada hal ini dapat dikatakan definisi dapat diterima karena bernilai benar. Hal ini sesuai dengan pendefinisian fakta oleh Bell (1981) dalam (Mahmudi, 2009).

Selanjutnya guru diminta memberikan contoh. Simbol adalah representasi dari fakta yang paling dominan diberikan para guru. Semua guru memahamai bahwa penyimbolan merupakan kesepakatan dalam matematika yang diterima secara luas sehingga tidak perlu diperkarakan. Simbol-simbol bermacam bilangan yang termasuk fakta merupakan contoh paling dominan. Berikutnya simbol-simbol dalam operasi, pertidaksamaan, ketidaksamaan, dan sejumlah simbol non operasi seperti simbol-simbol dalam himpunan, geometri, dan lainnya. Dapat dikatakan bahwa guru memiliki pemahaman yang baik mengenai contoh fakta. Hal ini dapat didasarkan pada pemahaman mengenai definisi fakta dengan baik pula.

Sementara itu terkait objek kedua yaitu konsep, terdapat sekitar 29\% guru mendefinisikan konsep dengan tepat menggunakan kata kunci 'ide abstrak' yang menungkinkan terjadinya penggolongan objek. Kelompok guru ini pun mampu memberikan contoh konsep dengan tepat namun secara terbatas. Contoh yang diberikan yaitu pada topik-topik geometri seperti bangun datar. Penjelasan konsep oleh guru bila dianalisis cenderung memberikan penekanan pada definisi. Hal ini sesuai dengan definisi konsep yang dapat diterima di mana konsep itu memerlukan ide asbtrak yang dibatasi menjadi sebuah definisi (Mahmudi, 2009). Misal dalam contoh yang diberikan guru, definisi segitiga sebagai sebuah bidang datar yang merupakan bidang datar yang dibatas tiga garis lurus. Sehingga setiap objek yang tidak memenuhi karakter pendefinisian, bisa dikatakan bukan segitiga. Bagi kelompok ini dapat dikatakan guru memahami konsep dengan baik dan mampu memberikan contoh konsep namun sangat terbatas. Tidak ada contoh lain yang mereka berikan berdasarkan hasil FGD yang dilakukan.

Selanjutnya, terdapat sekitar $47 \%$ peserta memberikan definisi yang tidak tepat. Kelompok guru ini mengasosiasikan konsep secara langsung sebagai 'materi' yang ada di setiap topik matematika sekolah. Melalui FGD ditemukan fakta bahwa guru dalam kelompok ini memandang bahwa pada topik matematika matriks, maka semua topik yang termuat di dalamnya merupakan konsep. Hal ini sangat mengejutkan 
mengingat kelompok ini memberikan informasi yang cukup signifikan mengenai kelemahan kelompok ini dalam memahami objek abstrak matematika secara keseluruhan. Namun, dari sejumlah respons tersebut, terdapat sebagian yang mereka sebutkan memang benar contoh dari konsep seperti 'apa itu matriks'. Meskipun demikian, masih terdapat kecendrungan meskipun relatif kecil bahwa kelompok ini masih memiliki pemahaman terkait konsep sebagai 'definisi'. Sekitar $28 \%$ dari $47 \%$ yang keliru dalam mendefinisikan objek sebagai ide abstrak, masih dapat memberikan contoh dengan benar di mana konsep diasosiakan sebagai definisi. Selanjutnya, sekitar 23,54\% guru tidak memberikan respons baik terhadap permintaan mendefinisikan objek konsep dan memberikan contohnya berdasarkan hasil FGD. Tampaknya, kelompok ini memang belum memahami abstrak konsep dengan baik.

Hasil FGD berikutnya terkait objek abstrak ketiga yakni prosedur. Hasil yang cukup menggembirakan ditemukan melalui FGD di mana $100 \%$ guru mengasosiasikan prosedur sebagai operasi. Hal ini senada dengan definisi Bell (1981) dalam (Mahmudi, 2009) yang mengatakan prosedur sebagai sebuah keterampilan dalam menjalankan langkah-langkah maupun operasi. Terkait permintaan memberikan contoh terhadap objek prosedur, sekelompok guru tersebut serta merta memberikan operasi pada bilangan riil sebagai contoh konkret operasi. Berdasarkan pertanyaan yang dilemparkan selama sesi FGD, ditemukan tidak ada contoh lain yang dapat diberikan oleh guru. Berdasarkan hasil tersebut, dapat dikatakan guru mampu mendefinisikan dan memberikan contoh prosedur dengan tepat. Namun, bila digali dari perspektif teori dan konten matematika sekolah menengah, definisi yang diberikan mempresentasikan keterbatasan dalam memahami prosedur secara utuh. Prosedur hanya diasosiasikan secara dangkal sebagai sebuah operasi pada topik bilangan saja. Hal ini dapat diterima mengingat kata operasi yang paling sering digunakan adalah operasi bilangan. Sehingga operasi dianggap hanya ada pada topik tersebut. Itulah alasan yang rasional mengapa pemberian contoh hanya terbatas pada topik bilangan. Mestinya pandangan di mana hampir semua topik matematika memuat prosedur dimiliki oleh guru. Diantaranya adalah operasi matriks, operasi himpunan, komposisi fungsi, operasi bentuk aljabar, bahkan di topik geometri sekalipun.

Terkait objek abstrak yang lebih komplet yaitu prinsip, ditemukan tidak ada guru yang dapat memberikan definisi beserta contoh prinsip beradasarkan sesi tanya jawab FGD. Salah satu guru mewakili kelompok ini dengan manyatakan bahwa prinsip belum dipahami dan bagian mana dalam materi matematika dalam topik tertentu dapat dikatakan prinsip. Hal ini dapat diterima di mana seseorang tidak akan mampu memberikan contoh bila definisi atau gambaran tentang objek apa yang difokuskan tidak dapat dipahami dengan baik. Hal ini juga merupakan sesuatu yang cukup mengejutkan mengingat prinsip sebagai objek yang komplet yang menggambarkan keterkaitan konsep salah satu di dalamnya tidak dipahami oleh guru.

Mengingat hasil yang ditemukan selama FGD beberapa hal dapat menjadi pembahasan. Secara umum objek matematika abstrak masih merupakan sektor yang sangat lemah di kalangan guru. Mengingat objek matematika ini sangat krusial untuk dipahami oleh pebelajar dalam hal ini guru sekalipun, maka hasil FGD memberikan gambaran yang cukup memprihatinkan bagi peneliti. Hal ini memberikan informasi kepada peneliti bahwa memahami matematika sekolah masih menjadi tantangan bagi para guru SMA Kabupaten Bintan. Hal ini mendukung klaim yang dilakukan oleh Sutiarso (2009). Lemahnya penguasaan terhadap objek matematika tersebut dapat diterima sebagai sebuah tantangan dan juga kendala dalam memahami matematika dari strukturnya (Holisin, 2016). Di atas situasi dan kondisi demikian, dapat disimpulkan bahwa kemampuan guru dalam mengurai suatu topik matematika ke dalam empat objek asbtrak masih menjadi problematika sekaligus tantangan. Hasil sementara dari FGD bahwa matematika cenderung diterima begitu saja (taken for granted) dan diajarkan tanpa adanya pemberian perhatian secara khusus terhadap struktur dan karakteristik konten atau materinya. Semua konten dalam topik matematika diajarkan dengan 'cara' yang sama. Hal ini memancing pemikiran berikutnya di mana problematika dan pengabaian ini merupakan sebuah kekhawatiran mengingat setiap objek matematika perlu penanganan yang unik ketika memahami dan mengajarkannya kepada peserta didik. 


\section{Kesimpulan}

Berdasarkan FGD yang dilakukan dapat disimpulkan bahwa hanya objek fakta yang dapat didefinsikan dengan baik dengan pemberikan contoh yang tepat dan luwes. Objek prosedur dipahami oleh semua guru namun dengan persepsi terbatas dengan pemberian contoh yang terbatas hanya pada konteks bilangan. Konsep sebagai sebuah didefinisikan sebagai ide abstrak dan juga diasosikan sebagai definisi oleh tidak lebih dari sepertiga guru dengan pemberian contoh yang terbatas. Pandangan mengenai konsep sebagai semua konten termuat dalam materi merupakan hal yang juga muncul di kalangan guru. Prinsip sebagai objek yang paling rumit tidak dipahami oleh semua guru dan di atas situasi tersebut pemberian contoh tidak dapat dilakukan. Analisis memberikan hasil empiris bahwa pemahaman guru SMA Kabupaten Bintan masih tergolong mengkhawatirkan mengingat matematika tidak seutuhnya dapat dipandang sebagai kumpulan struktur unik yang signifikan untuk dipelajari dan pahami dalam kepentingan proses pembelajaran.

\section{Saran}

Berdasarkan analisis terhadap data hasil kegiatan PkM ini, maka diperlukan penanganan yang serius terhadap pemahaman guru matematika mengenai karakteristik matematika dalam wujud penelitian tindakan maupun pelatihan untuk guru. Hal ini mengingat pentingnya memahami konten matematika dari strukturnya sebelum guru mengajarkan konten matematika tersebut.

\section{Referensi}

Afiyanti, Y. (2008). Focus group discussion (diskusi kelompok terfokus) sebagai metode pengumpulan data penelitian kualitatif. Jurnal Keperawatan Indonesia, 12(1), 58-62.

Astuti, P., \& Febrian, F. (2019). Diseminasi online multimedia pembelajaran matematika yang dikembangkan menggunakan videoscribe. Jurnal Anugerah: Jurnal Pengabdian Kepada Masyarakat Bidang Keguruan Dan Ilmu Pendidikan, 1(1), 19-24.

Bell, F. H. (1978). Teaching and learning mathematics (In secondary school). Wm, C. Browm Company Publisher.

Febrian, F., Astuti, P., \& Antika, R. (2019). Pelatihan pengembangan media videoscribe dengan konteks lokal dalam mengajarkan objek matematika bagi MGMP SMA Kabupaten Bintan. J-ABDIPAMAS (Jurnal Pengabdian Kepada Masyarakat), 3(2), 101-110.

Holisin, I. (2016). Pembelajaran Matematika Realistik (PMR). Didaktis: Jurnal Pendidikan Dan Ilmu Pengetahuan, 7(3).

Irwanto, I. (2006). Focus Group Discussion: A simple manual. Yayasan Obor.

Lailly, N. R., \& Wisudawati, A. W. (2015). Analisis soal tipe Higher Order Thinking Skill (HOTS) dalam soal UN kimia SMA Rayon B Tahun 2012/2013. Jurnal Kaunia, 11(1), 27-39.

Maarif, S. (2015). Integrasi matematika dan islam dalam pembelajaran matematika. Infinity Journal, 4(2), 223-236.

Mahmudi, A. (2009). Pengembangan pembelajaran matematika. Online. Tersedia: Http://staff. Uny. Ac. id/sites/default/files/tmp/Pengembangan\% 20Pemb, 20.

Ruseffendi, H. A. T. (2001). Pengantar kepada Membantu Guru Mengembangkan Kompetensinya dalam Pengajaran Matematika untuk Meningkatkan CBSA. Trasito.

Siregar, S. (2018). Meningkatkan kemampuan guru dalam menerapkan pembelajaran kontekstual melalui Focus Group Discussion (FGD) DI SMK Negeri 1 Sirandorung Tahun Pelajaran 2017/2018. NUSANTARA: Jurnal Ilmu Pengetahuan Sosial, 5(1), 14-19.

Sutiarso, S. (2009). Scaffolding dalam pembelajaran matematika. Prosiding Seminar Nasional Penelitian Pendidikan Dan Penerapan MIPA, 529. 